\title{
RANCANG BANGUN \& ANALISIS SISTEM SISTEM INFORMASI PERPUSTAKAAN MENGGUNAKAN MODEL WATERFALL (STUDI KASUS: STMIK WICIDA SAMARINDA)
}

\author{
Kusnandar \\ Teknik Informatika, STMIK Widya Cipta Dharma \\ J1. Prof. M. Yamin No. 25, Samarinda, 75123 \\ Email : ku5_n4nd4r@yahoo.com
}

\begin{abstract}
UPT. Library of College Management of Informatika Computer (STMIK) Wicida Samarinda East Kalimantan, representing peripatetic library in the field of loaning of books library of which can support student science. All activity at library still conducted manually, that is by noting every activity at one particular jotter.

Information system is a structure system which consists of components which is interaction to support activities to present information at one particular organization. Applying of information system at library can assist to facilitate activity of library, especially activity related to presentation of information at library.

Waterfall represent a model taking activity of elementary process like specification, development, validation, and evolution, and him as different process phases like specification of conditions, scheme of software, implementation, examination, and so on. Applying of model of waterfall at library information system expected can facilitate in activity of library especially in activity of loaning transaction and return of library book. Library book given by label of code (NIPUS) and membership card given by member number to facilitate process identify member and book at time of activity of loaning transaction and return. This research is expected can be made as media to water down activity at library, especially at UPT. Library of College Management of Informatika and Computer (STMIK) Wicida Samarinda East Kalimantan.
\end{abstract}

Keyword: Information System, Library, Waterfall.

\section{PENDAHULUAN}

Perpustakaan perguruan tinggi merupakan salah satu fasilitas yang disediakan oleh lembaga pendidikan sebagai pendukung dan penunjang proses kegiatan belajar mengajar bagi para mahasiswa. Keberadaan sebuah perpustakaan sangat membantu untuk menambah dan meningkatkan pengetahuan serta wawasan bagi para mahasiswa di lingkungan perguruan tinggi. Dengan meningkatkan fungsi perpustakaan secara maksimal oleh lembaga perguruan tinggi STMIK Wicida Samarinda, maka diharapkan menjadikan sebuah jaminan dalam memberikan pendidikan yang maksimal bagi para staf pengajar maupun mahasiswa. Memenuhi hal tersebut, salah satu langkah yang bisa langsung di implementasikan dalam meningkatkan fungsi perpustakaan perguruan tinggi adalah dengan penggunaan sistem informasi perpustakaan sehingga pengolahan data dilakukan secara tepat dan cepat.

Sistem informasi perpustakaan yang dibutuhkan oleh lembaga perguruan tinggi STMIK Wicida Samarinda, nantinya dipergunakan untuk tujuan transaksi pencatatan, transaksi pengolahan, transaksi penyimpanan, dan untuk melihat kembali transaksi-transaksi yang dilakukan, serta untuk menyalurkan informasi transaksi itu sendiri. Seiring dengan perkembangan teknologi dan informasi yang pada saat ini hampir mencakup semua bidang-bidang dalam kegiatan kehidupan manusia, maka hal ini bisa dimanfaatkan guna membangun sistem informasi perpustakaan yang berbasis komputerisasi. Perlu kita ketahui, komputer merupakan salah satu alat teknologi atau sarana yang bisa digunakan dalam membantu mewujudkan sistem informasi perpustakaan yang berbasis komputerisasi tersebut. Sehingga dengan terwujudnya sistem informasi tersebut akan diharapkan mempunyai nilai plus dibandingkan daripada sebuah sistem informasi perpustakaan yang diolah secara manual, serta akan menghasilkan suatu sistem informasi yang efektif, efisien dan mempunyai produktifitas yang tinggi dalam segi pelayanannya.

Berdasarkan pengamatan yang dilakukan oleh penulis didapati beberapa kendala yang dialami oleh perpustakaan STMIK Wicida saat ini, proses pendataan buku dan pendataan anggota dilakukan dengan menggunakan aplikasi excel, kesulitan adalah dala mendeteksi berapa jumlah buku yang dimiliki saat ini, jumlah buku yang keluar atau dipinjam tidak terdata dengan baik serta data peminjam yang tidak akurat dan banyak hal-hal lainnya. Proses pencarian buku pustaka yang dipinjam oleh anggota dilakukan dengan waktu yang relatif cukup lama, sehingga proses pelaporan kepada menajemen puncak juga sering mendapatkan kendala.

Berdasarkan hal tersebut diatas, penulis tertarik untuk mengembangkan aplikasi sistem informasi perpustakaan yang akan sedikit banyaknya meningkatkan kinerja manajemen perpustakaan STMIK Wicida, sistem informasi perpustakaan akan di kembangkan 
menggunakan model waterfall dengan di desain UML dan diimplementasikan dengan PHP mySQL.

Dari pengembangan menggunakan model waterfall, dalam pengembangan sistem informasi perpustakaan diharapkan komitmen harus dilakukan pada tahap awal proses, model waterfall harus digunakan hanya ketika persyaratan dipahami dengan baik. Bagaimanapun juga, model waterfall merefleksikan praktek rekayasa. Secara konsekuen, proses perangkat lunak yang berdasarkan pada pendekatan ini masih digunakan untuk pengembangan sistem informasi perpustakaan, terutama jika merupakan bagian dari sistem proyek rekayasa yang lebih besar. Selain itu, proses berdasarkan model waterfall dan pengembangan evolusioner dipakai secara luas untuk pengembangan sistem yang praktis, yang dapat dijadikan batu sandaran dalam pengembangan sistem informasi perpustakaan di STMIK Wicida Samarinda kedepannya.

\section{ANALISA SISTEM}

Dalam menganalisis sebuah sistem, biasanya akan dilakukan terhadap beberapa aspek antara lain adalah kinerja, informasi, ekonomi, keamanan aplikasi, efisiensi dan pelayanan pelanggan. Analisis ini disebut dengan PIECES Analysis (performance, information, economy, control, efficiency and service).

Analisis PIECES ini sangat penting untuk dilakukan sebelum menganalisis sebuah sitem informasi karena dalam analisis ini biasanya akan ditemukan beberapa masalah utama maupun masalah yang bersifat gejala dari masalah utama (Whitten, $2004:$ p88).

\section{SISTEM}

Sistem adalah sekumpulan komponen yang saling berhubungan dan bekerjasama untuk mencapai tujuan (Sommerville, 2003: p20).

\section{INFORMASI}

Segala sesuatu yang dapat dimanfaatkan sebagai dasar pengambilan keputusan pada dasarnya dapat dikelompokkan sebagai informasi (Nugroho, 2008: p15).

\section{Sistem Informasi Perpustakaan}

Perpustakaan Digital yaitu Perpustakaan dengan sistem informasi manajemen menggunakan teknologi informasi ditambah koleksi-koleksi digital baik berupa jurnal, ebook, CD audio, maupun koleksi video (Supriyanto, 2008: p18).

Perkembangan mutakhir adalah munculnya perpustakaan digital (digital library) yang memiliki keunggulan dalam kecepatan pengaksesan karena berorientasi ke data digital dan media jaringan komputer (internet). Di sisi lain, dari segi manajemen (teknik pengelolaan), dengan semakin kompleksnya koleksi perpustakaan, saat ini muncul kebutuhan akan penggunaan teknologi informasi untuk otomatisasi business process di perpustakaan. Sistem yang dikembangkan kemudian terkenal dengan sebutan sistem otomasi perpustakaan (library automation system) (Wahono : $2003: \mathrm{p} 1$ ).

Sistem informasi perpustakaan terdiri dari tiga kegiatan, yaitu inisialisasi buku, keanggotaan, dan pelayanan perpustakaan (Nugroho, 2008 : p146).

\section{MODEL WATERFALL}

Model ini mengambil kegiatan proses dasar seperti spesifikasi, pengembangan, validasi, dan evolusi, dan merepresentasikannya sebagai fase-fase proses yang berbeda seperti spesifikasi persyaratan, perancangan perangkat lunak, implementasi, pengujian, dan seterusnya (Sommerville, 2003, p; 42).

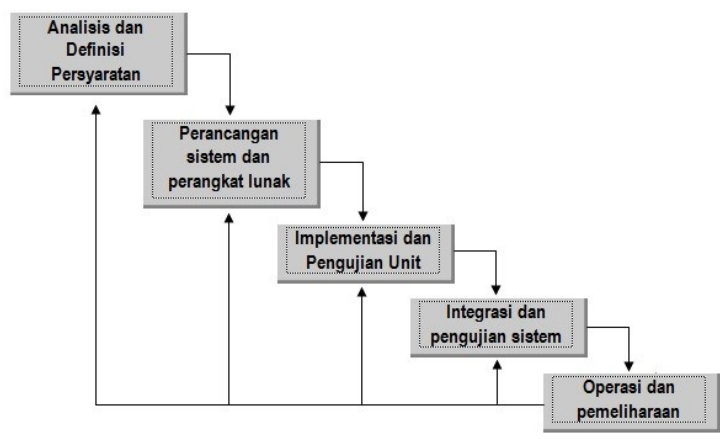

Gambar 1. Fase Model Waterfall

\section{KERANGKA PEMIKIRAN}

Penentuan daya dukung kegiatan administrasi perpustakaan dilakukan dengan cara mengetahui kapasitas sistem informasi perpustakaan yang digunakan bagi berlangsungnya kegiatan secara berkesinambungan dengan menggunakan model waterfall sehingga pengembangan sistem informasi perpustakaan bisa dilaksanakan sesuai dengan harapan. Tentunya, kapasitas dari pengembangan dengan menngunakan model waterfall inilah yang akan menjadi faktor pembatas dalam penentuan sistem informasi perpustakaan yang diterapkan pada STMIK wicida Samarinda.

Telaah sistem informasi perpustakaan dari pengembanganya dengan menggunakan model waterfall, terutama terhadap kelayakan pengimplementasian sistem yang dibuat pada perpustakaan STMIK Wicida Samarinda. Selanjutnya pengembangan dengan menggunakan model waterfall akan menentukan efektifnya terhadap pengembangan sistem informasi perpustakaan kedepannya. 


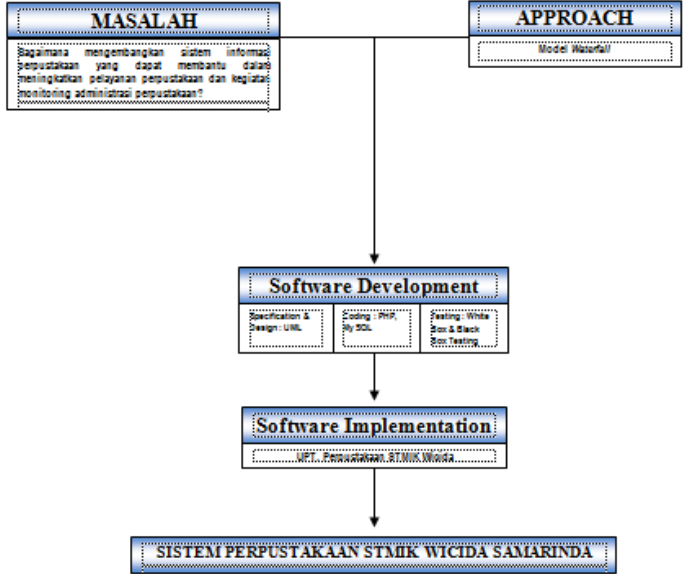

Gambar 2. Kerangka Pemikiran konsep penelitian Pengembangan Sistem Informasi Perpustakaan Menggunakan Model Waterfall pada STMIK Wicida Samarinda.

\section{METODE PENELITIAN}

\section{Analisis Kebutuhan}

Dalam pengumpulan data, akan digunakan beberapa metode untuk menentukan kebutuhan sistem yang akan dibangun. Adapun metode yang digunakan adalah:

a. Metode Observasi

Observasi yaitu melakukan pengamatan secara langsung ke objek penelitian untuk melihat dari dekat kegiatan yang dilakukan. Apabila objek penelitian bersifat perilaku dan tindakan manusia, fenomena alam (kejadian-kejadian yang ada di alam sekitar), dan proses kerja.

b. Metode Wawancara

Adalah suatu cara pengumpulan data yang digunakan untuk memperoleh informasi langsung dari sumbernya. Wawancara ini digunakan bila ingin mengetahui hal-hal dari user secara lebih mendalam.

Ada beberapa faktor yang mempengaruhi arus informasi dalam wawancara, yaitu : pewawancara, user, pedoman wawancara, dan situasi wawancara. Sedangkan, dalam wawancara ini sendiri terdiri dari wawancara terpimpin, wawancara bebas, dan wawancara bebas terpimpin. (Sugiyono, 2010 , p;14)

c. Observasi Lapangan

Adalah merupakan suatu kegiatan yang dilakukan oleh peneliti terjun langsung ke lokasi penelitian untuk mengamati subjek dan aspek-aspek yang diamati. Observasi lapangan dapat menjamin bahwa peneliti mencatat tiap-tiap kejadian sekecil apapun yang dianggap penting dalam melakukan penelitian.

\section{Perancangan Penelitian}

Bagaimana upaya pengembangan sistem informasi perpustakaan menggunakan model waterfall akan didapatkan beberapa penemuan, pembuktian dan pengembangan dari sistem tersebut. Selain itu, perancangan penelitian didasarkan pada:

a. Tahap Perencanaan (Rekayasa Sistem dan Analisis), dilakukan untuk mencoba memahami permasalahan yang muncul dan mendefinisikan secara rinci, kemudian menentukan tujuan pembuatan sistem dan mengidentifikasi kendala-kendalanya, lalu mempersiapkan usulan penelitian.

b. Tahap Analisis, merupakan tahapan yang lebih dalam mengenai sistem, tujuan, dan fungsi yang dilakukan sistem.

c. Tahap Perancangan, salah satu tahapan untuk mennetukan konfigurasi apa saja yang dibutuhkan oleh sistem dan metode yang digunakan dalam pengambilan keputusan. Perancangan perangkat lunak yang juga termasuk didalamnya adalah proses, aturan yang digunakan user interface, susunan menu dan inputan yang dibutuhkan.

d. Tahap Penerapan, kegiatan tahapan ini merupakan kegiatan pengimplementasian desain menjadi sebuah program.

e. Tahap Evaluasi (Pengujian), dilakukan untuk menguji bagaimana cara pemakaian alat-alat pada sebuah sistem yang ada. Proses uji coba ini diperlukan untuk memastikan bahwa sistem ini sudah benar. Sesuai karakteristik yang ditetapkan dan tidak ada kesalahankesalahan yang terkandung didalamnya.

f. Tahap Pemeliharaan, merupakan tahapan finally terhadap sistem yang telah dibuat menjadi sebuah program, dengan tujuan untuk mengatasi kemungkinan yang akan terjadi seperti memperbaiki kesalahan, menjaga kemuktahiran sistem serta meningkatkan sistem.

g. Rasional, kegiatan penelitian dilakukan dengan caracara yang masuk akal sehingga terjangkau oleh penalaran manusia.

h. Empiris, cara-cara yang digunakan dalam penelitian itu teramati oleh indera manusia, sehingga orang lain dapat mengamati dan mengetahui cara-cara yang akan digunakan.

i. Sistematis, proses yang digunakan dalam penelitian itu menggunakan langkah-langkah tertentu yang bersifat logis.

Dengan perancangan yang secara bertahap dilakukan tentunya dapat digunakan dalam pengembangan sistem informasi perpustakaan menggunakan model waterfall. 


\section{Metode Pemrograman}

Rekayasa Perangkat Lunak Adalah penggunaan prinsip-prinsip rekayasa yang benar untuk menghasilkan perangkat lunak ekonomis yang dapat diandalkan dan dapat bekerja secara efisien. Dalam pengembangan sistem ini menggunakan gabungan antara pendekatan pemrograman terstruktur dan pemrograman berorientasi objek.

Untuk bahasa pemrograman yang digunakan adalah PHP, yaitu bahasa pemrograman yang sangat populer untuk membangun aplikasi berbasis web. Sedangkan untuk databasenya menggunakan MySQL, yang merupakan software DBMS yang handal dan dapat diperoleh serta digunakan secara gratis.

\section{DESAIN SISTEM}

Tahapan desain sistem dalam perancangan prototype Sistem Informasi Perpustakaan ini menggunakan metode UML (Unified Modeling Language) yaitu suatu metode modeling generasi ketiga dan bahasa spesifikasi yang sifatnya non-proprietary.

Dalam penggunaan dari metode UML itu sendiri tidak terbatas hanya pada dunia software modeling, tetapi bisa pula digunakan untuk modeling hardware (engineering systems) dan sering digunakan sebagai modeling untuk proses bisnis dan juga modeling untuk struktur organisasi. Selain perangkat yang telah disampaikan diatas, dalam penelitian ini untuk pembuatan relasi antar tabel menggunakan software aplikasi Power Designer, merupakan suatu aplikasi yang memudahkan dalam mendesain gambar khususnya pembuatan relasi antar tabel pada sistem informasi perpustakaan UPT. Perpustakaan STMIK Wicida Samarinda.

Bahasa sederhananya, dalam pelaksanaan penelitian pengembangan sistem informasi perpustakaan ini, untuk mendapatkan perancangan suatu desain prototype Sistem Informasi Perpustakaan hanya menggunakan beberapa jenis standar diagram Unified Modeling Language (UML), seperti Use case diagram, Class Diagram, Activity Diagram, dan Squence Diagram karena dianggap sudah mencukupi untuk menyelesaikan kasus ini.

\section{Use Case Diagram}

Use case diagram pada sistem informasi perpustakaan ini menggambarkan kegiatan-kegiatan dari actor yang terdiri dari staf perpustakaan, kepala perpustakaan, dan anggota perpustakaan dalam melaksanakan kegiatankegiatan di unit perpustakaan.

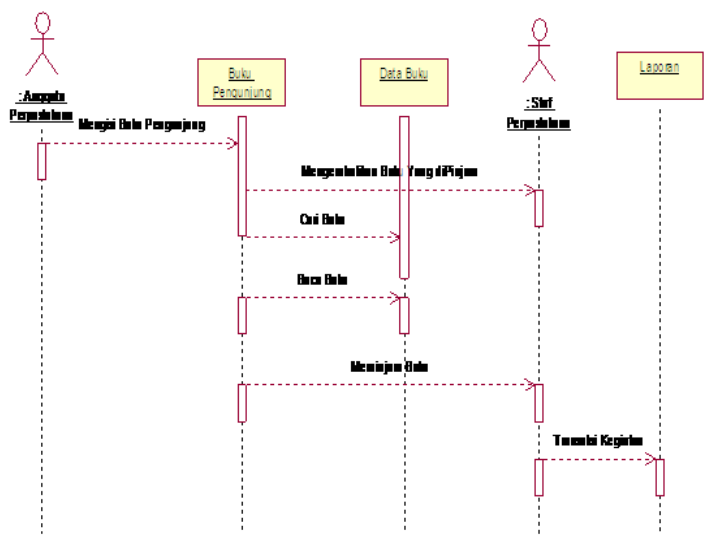

Gambar 3. Use Case Diagram

\section{Class Diagram}

Class diagram adalah jenis diagram struktur statis yang menggambarkan struktur sistem dengan menunjukkan sistem, atribut mereka, operasi (atau) metode dan hubungan antara kelas-kelas.

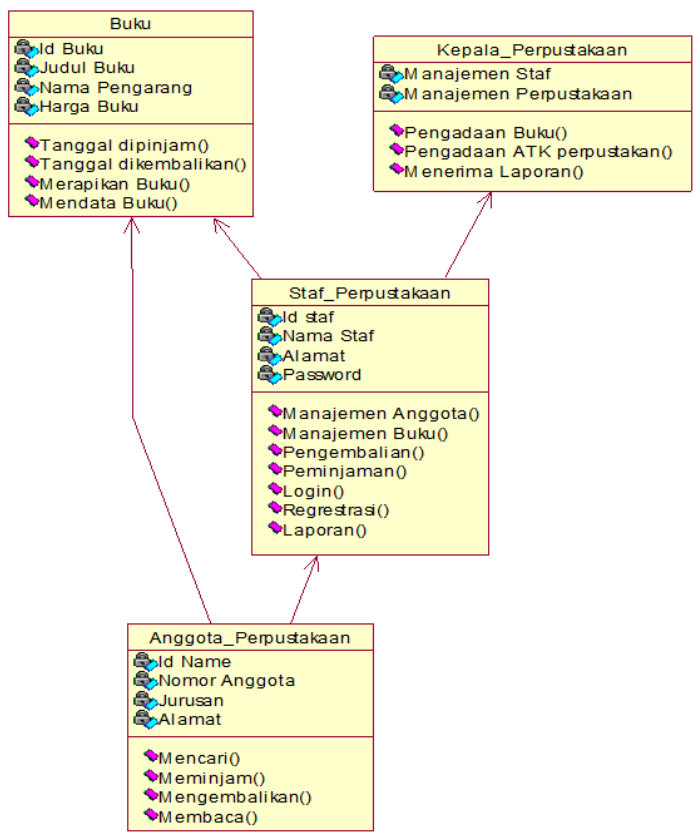

Gambar 4. Class Diagram

\section{Sequence Diagram}

Sequence diagram adalah sejenis interaksi diagram yang menunjukkan bagaimana suatu proses berjalan, antara satu dengan yang lain didalam sebuah urutan yang telah ditentukan 


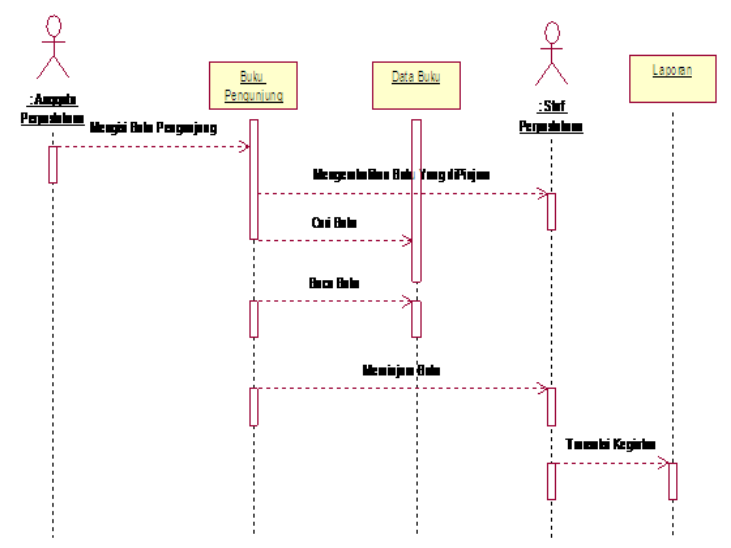

Gambar 5 Sequence Diagram

\section{Activity Diagram Registrasi}

Pada diagram activity ini menggambarkan tentang proses registrasi atau pendaftaran bagi anggota baru perpustakaan, dimana pengunjung yang belum menjadi anggota dari perpustakaan untuk menjadi anggota perpustakaan harus melalui proses gambar ini.

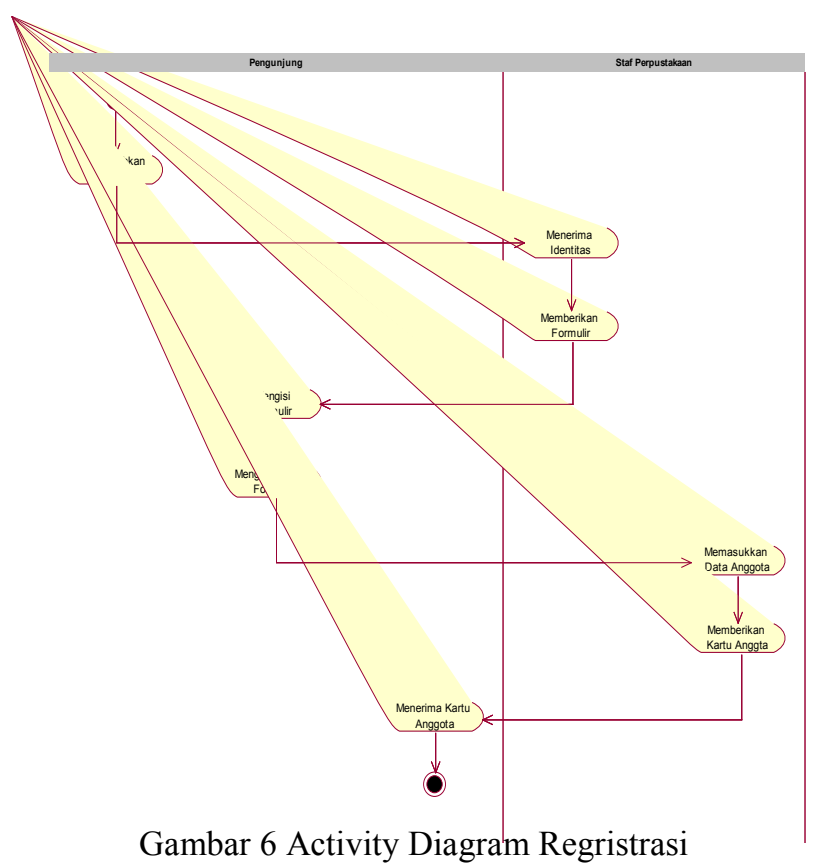

\section{Activity Diaagram Buku Pengunjung}

Pada diagram activity ini merupakan tentang suatu proses anggota perpustakaan yang berkunjung kedalam perpustakaan, dimana anggota sebagai pengunjung diharuskan mengisi buku pengunjung yang proses terlihat melalui gambar di samping ini.

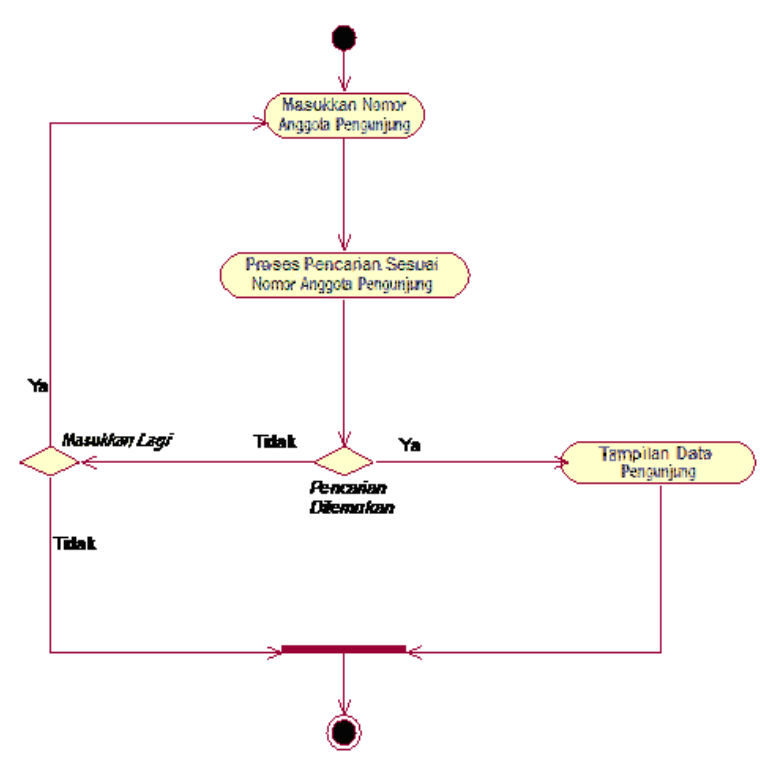

Gambar 7 Activity Diagram Buku Pengunjung

\section{Activity Diagram Manajemen Buku}

Pada diagram ini merupakan proses manajemen buku dimana petugas perpustakaan melakukan proses manajemen buku. Petugas perpustakaan melakukan proses menambah data buku, mengubah data buku, menghapus data buku dan membuat laporan data buku yang terdapat di perpustakaan.

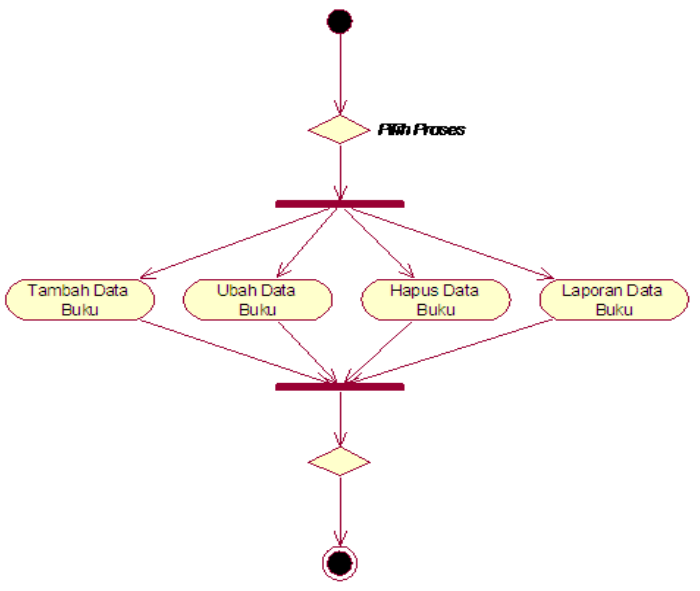

Gambar 8 Activity Diagram Manajemen Buku

\section{Activity Diagram Manajemen Anggota}

Pada gambar berikut merupakan proses manajemen anggota dimana petugas perpustakan melakukan proses manajemen anggota, dimana petugas perustakaan melakukan proses menambah data anggota, mengubah data anggota, menghapus data anggota dan membuat laporan data aggota yang telah terdaftar di perpustakaan. 


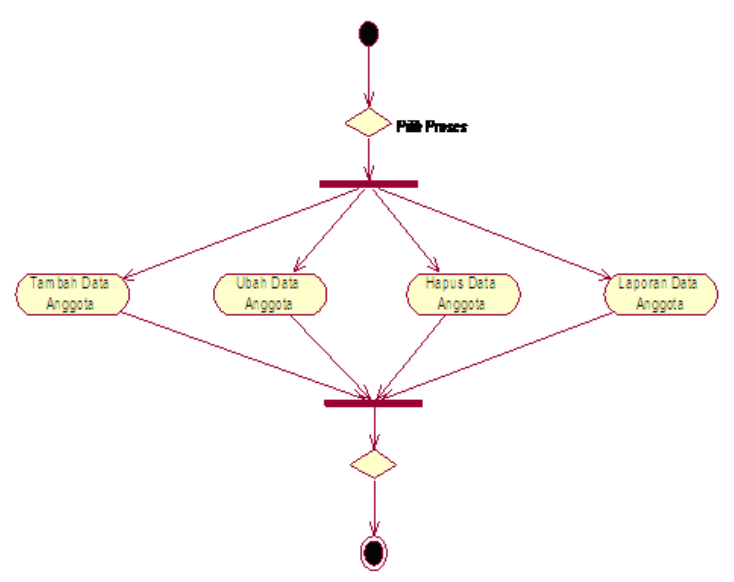

Gambar 9 Activity Diagram Manajemen Anggota

\section{Activity Diagram Proses Peminjaman Buku}

Pada gambar berikut, suatu proses peminjaman buku dimana anggota melakukan pencarian buku yang dikehendaki, setelah menemukan maka anggota tersebut akan menyerahkan buku yang dipinjam dan kartu anggota kepada petugas perpustakaan, kemudian petugas membaca atau menscanning kartu anggota dan Nipus buku, setelah terdata dan petugas menyimpan data peminjaman tersebut. Anggota menerima buku yang dipinjamnya.

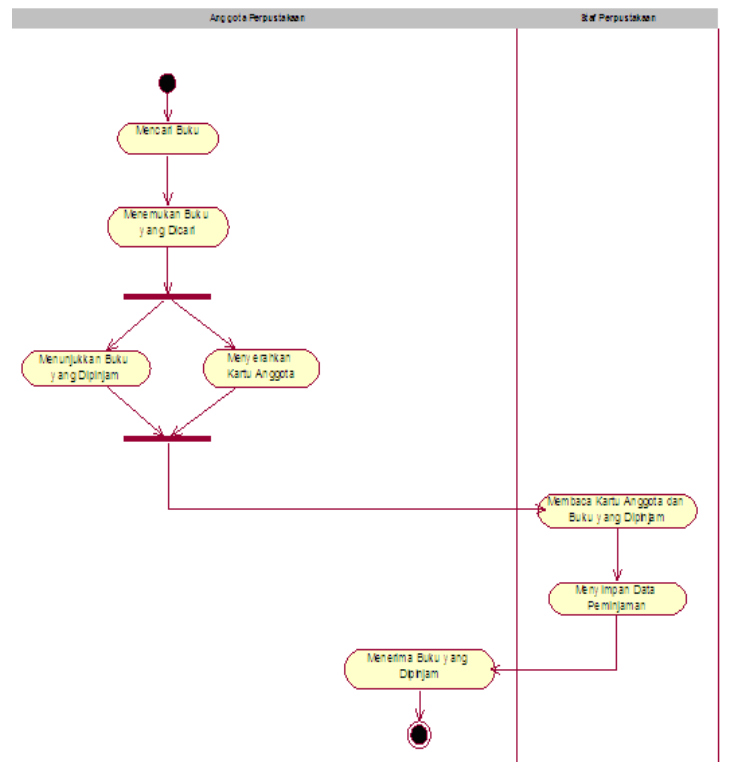

Gambar 10 Activity Diagram Proses Peminjaman Buku

\section{Activity Diagram Proses Pengembalian Buku}

Pada gambar activity berikut merupakan proses pengembalian buku dimana anggota menyerahkan buku yang hendak dikembalikan kepada petugas perpustakaan, kemudian sistem akan memproses data peminjaman, apabila pengembalian buku mengalami keterlambatan maka sistem akan mengenakan denda maka anggota diharuskan membayar denda sesuai dengan yang tercatat di sistem dan sebaliknya.

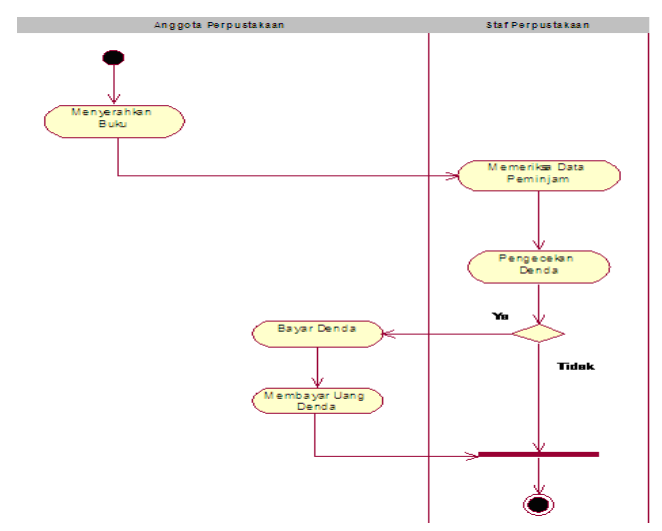

Gambar 11 Activity Diagram Proses Pengembalian Buku

\section{Activity Diagram Proses Pencarian Buku}

Pada gambar activity diagram proses pencarian buku suatu langkah bagaimana proses pencarian buku dilakukan oleh anggota perpustakaan, pengunjung ataupun petugas perpustakaan. Pencarian data buku dilakukan berdasarkan kata kunci, yaitu berdasarkan kode buku, judul buku ataupun berdasarkan pengarang. Jika data ditemukan maka akan ditampilkan hasil pencarian pada layar.

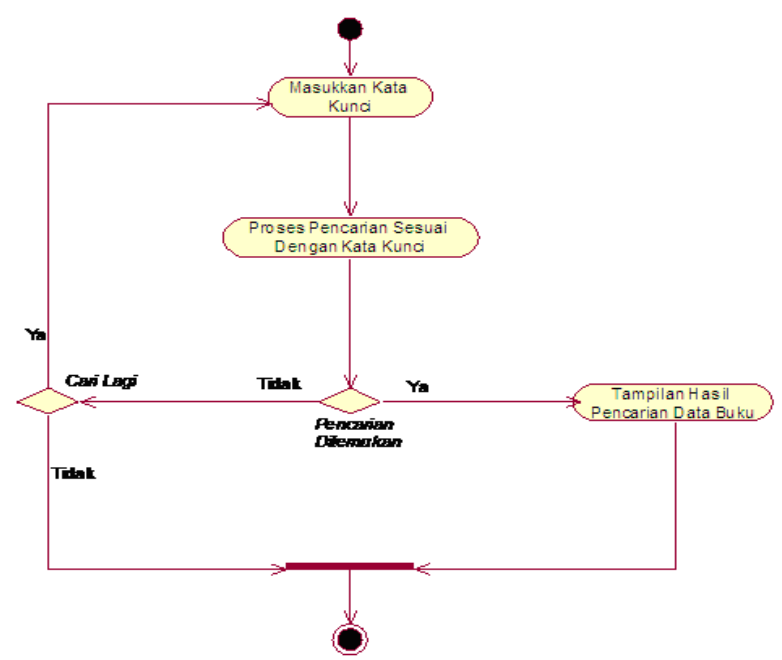

Gambar 12 Activity Diagram Proses Pencarian Buku

\section{Activity Diagram Proses Laporan}

Pada gambar dibawah ini merupakan proses laporan kegiatan transaksi perpustakaan baik dalam satu hari, satu bulan, satu semester, dan satu tahun yang dilakukan oleh staf perpustakaan kepada kepala perpustakaan. 


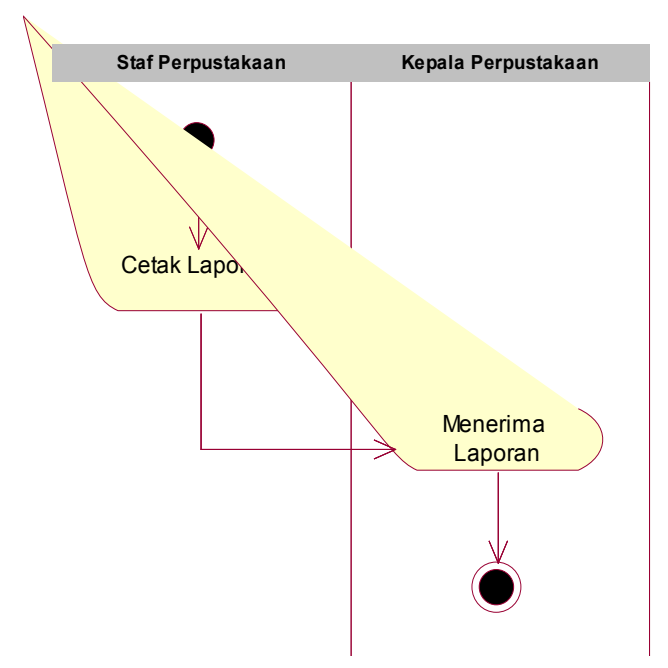

Gambar 13 Activity Diagram Proses Laporan

\section{HASIL DAN PEMBAHASAN}

Pada bab sebelumnya telah di kemukakan desain dari sistem yang akan dikembangkan, dan hasilnya akan di tampilkan pada bab IV ini, secara keseluruhan untuk tahapan-tahapannya sesuai dengan model yang digunakan yaitu menggunakan model waterfall. Dalam pengujian sistem ini akan dibahas melalui hasil pengujian white box dan black box.

Selanjutnya, model waterfall pada tahapan-tahapannya dalam peneltian pengembangan sistem informasi perpustakaan perguruan tinggi STMIK Wicida Samarinda adalah sebagai berikut:

\section{Analisis dan Definisi Persyaratan}

Tahapan ini memberikan gambaran proses awal dibuatnya perangkat lunak sistem informasi perpustakaan, langkah pertama yang akan dilakukan disesuaikan dengan model waterfall yang digunakan adalah menganalisis akan definisi persyaratan pelayanan, batasan, dan tujuan sistem ditentukan melalui konsultasi dengan admin/user sistem pada UPT Perpustakaan STMIK Wicida. Persyaratan ini kemudian didefinisikan secara rinci serta sekaligus berfungsi sebagai spesifikasi sistem tersebut. Hasil penelitian yang dilakukan dapat dijelaskan sebagai berikut :

\section{Pendataan Buku}

Pada saat di lakukan wawancara serta observasi dilapangan, buku-buku yang ada diperpustakaan STMIK Wicida Samarinda diperoleh dari perguruan tinggi STMIK Wicida, mahasiswa, dan sumbangan dari pihak pemerintah/swasta. Kemudian admin/user sebagai staf di UPT Perpustakaan mendata buku-buku tersebut kedalam sistem manual. Buku yang telah di terima dan di input oleh admin/user selanjutnya di cetakan Nomor
Induk Pustaka (NIPus) bertujuan untuk memberi identitas pada buku agar mempermudah dalam pencarian buku perpustakaan. Setelah semua buku-buku di tempel dengan cetakan NIPus, admin/user selaku staf perpustakaan meletakkan buku-buku itu dalam lemari dan rak pustaka sesuai dengan NIPus yang tertera pada buku.

Data buku yang telah di input disimpan dalam harddisk komputer dan juga di cetak untuk dijadikan arsip berupa laporan data buku bagi pihak-pihak yang berkepentingan. Fungsi dari laporan data buku akan memberikan informasi tentang keadaan buku perpustakaan yang ada di UPT Perpustakaan STMIK Wicida Samarinda. Serta memberikan kemudahan bagi para donatur untuk menyumbangkan dan mengadakan buku-buku yang belum ada serta yang dibutuhkan oleh anggota perpustakaan. Selain itu, laporan data buku perpustakaan dapat memberikan informasi pihak-pihak sebagai donatur/penyumbang buku di UPT Perpustakaan STMIK Wicida Samarinda.

\section{Pendataan Anggota}

Kegiatan pendataan anggota dimulai dari permohonan anggota perpustakaan oleh mahasiswa (umum) segera mengisi formulir permohonan menjadi anggota perpustakaan yang diberi oleh staf UPT Perpustakaan STMIK Wicida Samarinda. Setelah mendapatkan formulir permohonan calon anggota perpustakaan mengisi sesuai permintaan data di formulir dengan jelas dan benar, lalu diserahkan kembali kepada staf perpustakaan. Kemudian, oleh staf perpustakaan melakukan penginputan data sesuai isian di lembar formulir.

Staf perpustakaan mengarsipkan lembar formulir yang telah diterima dan membuat kartu anggota perpustakaan serta memberikannya kepada mahasiswa (umum) untuk "menandakan" yang bersangkutan resmi menjadi anggota perpustakaan.

Staf perpustakaan membuat laporan data angggota perpustakaan perbulan, sebagai masukkan bagi kepala perpustakaan dan perguruan tinggi tentang informasi seberapa banyak anggota perpustakaan. Tujuannya, dengan adanya informasi laporan data anggota perpustakaan dapat memberikan kepada pihak-pihak yang berkepentingan untuk meningkatkan kuantitas buku-buku perpustakaan. Sehingga dapat membantu dan melayani anggota perpustakaan dalam mencari serta menambah referensi pustaka untuk tugas-tugas kuliah dan penyelesaian tugas akhir. 


\section{Transaksi}

Mulai dari pendataan buku dan pendataan anggota yang telah di jabarkan pada poin diatas, maka dapat digambarkan aliran dokumen yang terjadi yaitu pada staf perpustakaan dalam mendata buku-buku yang diperoleh dari donatur dan mendata anggota perpustakaan merupakan kegiatan pelayanan perpustakaan. Pada saat semuanya berjalan, timbul transaksi peminjaman dan pengembalian buku oleh anggota perpustakaan.

Transaksi peminjaman ini sendiri, diakui oleh staf perpustakaan merupakan kegiatan transaksi yang sangat "melelahkan" disebabkan oleh perlunya mendata biodata peminjam secara manual. Tentunya, berdampak terlalu lamanya waktu untuk melayani satu anggota perpustakaan, bagaimana bila peminjam lebih banyak maka akan memakan waktu yang lama sehingga kegiatan pelayanan perpustakaan menjadi tidak efektif dan efesien.

Transaksi pengembalian, di lakukan pada saat anggota perpustakaan megembalikan buku yang dipinjamnya. Untuk waktu dalam melayani kegiatan pengembalian tidak lama seperti pada kegiatan pelayanan transaksi peminjaman, namun dari sisi kecepatan pelayanan masih belum memuaskan karena menumpuknya anggota untuk mengembalikan dan memperpanjang waktu peminjaman buku.

\section{Lihat Data}

Gambaran bagi pihak-pihak yang berkepentingan ingin melihat data-data yang terdapat pada UPT Perpustakaan STMIK Wicida, akan mendapatkan beberapa kesulitan seperti contoh salah satunya harus menunggu di ambilkan dokumen arsip yang dsimpan secara manual.

Output dari Sistem Informasi Perpustakaan Menggunakan Model Waterfall memberikan informasiinformasi yang akan sangat membantu kepala UPT Perpustakaan STMIK Wicida dan pihak-pihak yang berkepentingan dalam mengambil keputusan serta menghasilkan informasi yang cepat dan akurat baik untuk keperluan internal maupun untuk pihak eksternal yang membutuhkannya.

Output yang dihasilkan diantaranya informasi :

1. Laporan Data Buku

2. Laporan Data Anggota

3. Laporan Data Pengunjung

4. Laporan Transaski Peminjaman Buku

5. Laporan Transaksi Pengembalian Buku.

6. Laporan Data Surat Bebas Pustaka

\section{ASPEK MANAJERIAL}

Dari sisi manajerial dengan di implementasikannya sistem informasi di dapat implikasi yang sangat bagus yaitu berupa masukkan bagi manajerial untuk meningkatkan sarana dan prasarana unit perpustakaan STMIK Wicida. Selain itu, semakin membaiknya dari aspek manajemen akan meningkatkan kualitas pelayanan dari kegiatan transaksi perpustakaan bagi anggotanya.

Sumber daya manusia (SDM) yang dimiliki dapat di lakukan pembenahan dengan dilakukannya pemberian pelatihan-pelatihan mengenai penggunaan sistem yang ada. Ketika suatu saat perlu merekrut staf perpustakaan, tentunya adanya seleksi yang akurat guna meningkatkan SDM yang sudah ada sebelumnya dalam menjalankan kegiatan perpustakaan.

Aspek manajerial sendiri akan mudah dihubungkan dan menerapkan langkah-langkah baik POAC yaitu planning, organizing, actuating, controling, serta SWOT yaitu strenght, weakness, oppurtunities, tread. $\mathrm{Ke}$ depannya mampu berkembang serta bersaing dengan perpustakaan-perpustakaan lainnya. Harapan lainnya, dapat memberikan jendela baru bagi perpustakaan khusunya bagi perpguruan STMIK Wicida dan umumnya bagi dunia perpustakaan.

\section{Aspek Penelitian Lanjutan}

Implikasi dari penggunaan sistem informasi perpsutakaan STMIK Wicida Samarinda dalam aspek penelitian merupakan kewajiban adanya suatu relasi yang harus signifikan, disebabkan dengan dilakukannya penelitian yang berkualitas akan didapat suatu pengembangan sistem informasi perpustakaan yang mendekati kesempurnaan. Dengan mendekati kesempurnaan, ketika dijadikan rujukan bagi penelitian ke depannya di bidang yang sama akan memudahkan untuk memberikan hasil yang mengarah kepada kesempurnaan.

Aspek penelitian sendiri dapat dilihat dari satu sisi yang sama-sama sangat membutuhkanya keakuratan semua data yang didapat dan di tuangkan dalam penulisan. Sehingga, untuk penulisan saat ini akan dapat dikatakan penulisan yang berkualitas dan juga ke depannya sebagai penelitian yang dapat dipakai rujukan yang berkualitas.

\section{Analisis}

Dari pembahasan yang telah dijabarkan diatas, analisa penulis dapat di jelaskan berdasarkan model waterfall yang digunakan terhadap pengembangan sistem informasi perpustakaan STMIK Wicida adalah sebagai berikut:

\section{Analisis dan Definisi Persyaratan}

Yang dilakukan pada proses tahapan ini yaitu mengumpulkan kebutuhan-kebutuhan user secara lengkap untuk melakukan pengembangan sistem perpustakaan 
yang diinginkan oleh user. Kebutuhan yang telah didapat kemudian di analisis dan juga di definisikan, agar memudahkan dalam pengembangan sistem informasi perpustakaan tersebut. Saat dilakukan tahapan ini ternyata user belum mempunyai sistem informasi perpustakaan untuk digunakan dalam kegiatan mendata buku, mendata anggota, melakukan transaksi, lihat data, pembuatan surat bebas pustaka, dan pembagian pada administrator/user. Pada pengembangan sistem perpustakaan ini, semua pendataan dikerjakan dan dilakukan oleh staf perpustakaan. Maka staf perpustakaan harus menginput setiap data yang terjadi didalam kegiatan perpustakaan sehingga pendataan yang dilakukan berjalan sesuai dengan sistem informasi perpustakaan yang telah dibuat sesuai analisis dan persyaratan yang ada.

Secara pelaksanaannya, sebenarnya tahapan ini telah menghasilkan kebutuhan pada sistem perpustakaan dan user dapat menjalankan sistem tersebut. Namun, ada beberapa hal penting yaitu pada saat tahapan-tahapan yang dilakukan baik dalam pendataan buku, pendataan anggota, transaksi, lihat data, surat bebas pustaka, dan administrator, ternyata masih perlu adanya tambahantambahan dari sisi tampilan, menu dan option dari menu . Dari hal tersebut diatas, setelah dilakukan analisis dan definisi akan kebutuhan-kebutuhan dari user, maka langsung di informasikan kekurangan yang ditemukan ke user. Sehingga, dalam pengembangan sistem informasi perpustakaan akhirnya lebih baik dan lebih mudah untuk di jalankan. Dan inipun bukan merupakan kebutuhan akhir dari user dalam pengembangan sistem perpustakaan pada perguruan tinggi STMIK Wicida Samarinda.

\section{Perancangan Sistem dan Perangkat Lunak}

Setelah dilaksanakannya tahapan pertama diatas, berikutnya adalah tahapan proses untuk memindahkan kebutuhan-kebutuhan tersebut kedalam bentuk proses rancangan sistem serta bentuk desain perangkat lunak yang mudah dimengerti dan dipahami oleh user. Untuk bentuk proses tersebut dibuat sebuah dokumentasi yang berbentuk proposal serta di presentasikan kepada kepala perpustakaan dan jajaran manajerial yang berhubungan dengan sistem ini. Tujuannya, mendapatkan persetujuan lembaga serta tambahan masukkan kebutuhan sistem sebelumnya. Setelah itu, dapat dilaksanakan pengembangan sistem dengan terlebih dahulu membaca dan mempelajari desain sistem dan desain perangkat lunak yang telah di bentuk dalam proses. Pengembangan sistem dibuat dokumentasi berupa desain proses rancangan sistem dan perangkat lunak dengan menggunakan prototype UML (Unified Modeling Language), relasi antar tabel menggunakan aplikasi Power Designer, dan perancangan antar muka (desain interface). Dengan dokumentasi diatas akan semakin jelas arah rancangan sistem dan perangkat lunak dalam pengembangan sistem tersebut.

Implementasi dan Pengujian Unit

Setelah tahapan desain rancangan sistem dan pengembangan perangkat lunak diterima dan dilaksanakan. Tentunya, dibuktikan dengan kesepakatan antara pengembang dan pengguna yang sudah ditanda tangani oleh manajemen tentang kegiatan prosesnya. Langkah selanjutnya adalah pembuatan program yang didalam pembuatannya penulis menggunakan bahasa pemrograman berbasis web PHP standart dan databasenye menggunakan MySQL, Program sistem informasi perpustakaan dibuat dalam bentuk menu-menu yang mudah dimengerti dan sudah ditentukan serta disetujui oleh administrator. Implementasi dilakukan untuk melihat keamanan database dan programnya, serta melihat dari sisi kemudahan dalam menjalankan database dan programnya. Penulis juga melakukan pengujian unit salah satunya pengujian unit verifikasi login dan password didalam proses pertama program saat akan dijalankan. Untuk user/admin yang akan mengakses program akan ditentukan hak aksesnya untuk membedakan otorisasi masing-masing user/admin tersebut.

\section{Integrasi dan Pengujian Sistem}

Saat pengembangan rancangan sistem dan perangkat lunak telah selesai dilaksanakan. Selanjutnya program sistem akan diserahkan ke pengguna/user namun sebelumnya harus dilakukan pengujian terlebih dahulu guna mencari segala kemungkinan adanya kesalahan program secara logik atau pada kegiatan prosesnya. Sehingga dapat di ketahui apakah sesuai pada batasanbatasan dan permintaan yang sudah di tentukan sebelumnya atau tidak. Pengujian program yang dilakukan terdiri dari pengujian White Box yaitu suatu metode desain test case yang menggunakan struktur kontrol desain prosedural untuk memperoleh test case, dan Black Box yaitu pengujian user interface dimana setelah aplikasi system informasi perpustakaan dapat dioperasikan dengan baik.

Maka dasar dari program tersebut sudah layak untuk diserah terimakan ke user. Sedangkan dalam serah terima tersebut dengan melalui 3 tahap pengenalan sistem. Setiap tahap terdapat dokumen yang harus di tandatangani oleh setiap user yang mengoperasikan sistem sebagai bukti bahwa user tersebut sudah tahu dan dapat mengoperasikannya dengan benar. Pada tahap pertama yaitu merupakan pengenalan program/user training, dimana dalam tahap ini user dan manajemen akan dikenalkan dengan sistem informasi perpustakaan yang sudah didesain bersama-sama dalam hal proses kegiatannya. Untuk pelaksanaan tahap pertama ini 
membutuhkan waktu selama satu hari. Mengapa pada tahap pertama ini pelaksanaannya menggunakan waktu selama satu hari?, karena menurut penulis dengan waktu satu hari maka akan efektif dari sisi pengenalan program sistem serta efesien dari sisi biaya yang pasti muncul dari kegiatan tahap pertama ini. Tahap kedua adalah User testing dimana dalam tahap ini user membutuhkan waktu 4 sampai 5 jam untuk melaksanakan mulai dari login ke dalam program lalu melakukan pendataan buku, pendataan anggota, melakukan kegiatan transaksi, lihat data, surat bebas pustaka, dan sampai kepada otorisasi Administrator. Sehingga user dapat pula menyajikan laporan-laporan yang sesuai dengan kegiatan. Tahap kedua ini membutuhkan waktu 4 sampai 5 jam dikarenakan user tinggal melakukan percobaan dimana pada tahap pertama sudah mengenal akan seluruh program sistem tersebut. Jadi, tidak membutuhkan waktu selama satu hari. Tahap terakhir atau yang ketiga adalah User Accepted Training (UAT) yaitu merupakan latihan input data hampir sama dengan tahap kedua user testing diatas namun pada tahap ini data yang di input menggunakan data yang benar. Pelaksanaan untuk tahap ketiga ini menurut penulis agar efektif serta efesien waktu yang di perlukan sekitar 2 sampai 3 jam.

\section{Operasi dan Pemeliharaan}

Setelah ke empat tahapan dilaksanakan, maka pada tahap terakhir dalam pengembangan sistem menggunakan model waterfall yang penulis buat adalah perawatan program, itupun akan dilakukan setelah program sudah benar-benar digunakan oleh user. Ketika program sistem informasi sudah digunakan dan dianggap layak untuk dijalankan maka tahapan terakhir ini yaitu melakukan perawatan program, dimana dalam perawatan program ini berguna dalam proses pengembangan sistem selanjutnya. Pada kegiatan perawatan program sistem penulis menerapkan tiga macam jenis perawatan, pertama perawatan corrective yaitu sebuah perawatan yang dilakukan jika terjadi kesalahan pada program/sistem atau biasa dikenal dengan istilah bugs, perawatannya adalah dengan cara memperbaiki source codenya lalu dicompile kembali agar dapat digunakan.

Untuk perawatan kedua merupakan perawatan routine atau perawatan preventive maintenance dimana dalam perawatan ini dilakukan secara periodik untuk melihat kinerja program saat dijalankan sehingga dapat di monitor jika terjadi masalah-masalah dari koneksi jaringannya. Dalam perawatan ini, menurut penulis dapat digunakan untuk penambahan proses kemampuan atau kinerja program sistem seperti memberikan fungsi-fungsi tambahan diluar dari desain kegiatan proses yang sudah dibuat sebelumnya pada saat setelah melalui proses desain ulang bersama-sama.

Perawatan ketiga adalah suatu perawatan pada sistem upgrade yang akan dilakukan jika ada perubahan dari komponen-komponen yang terlibat dalam program tersebut, seperti perubahan platform sistem operasi atau perubahan standart bahasa pemrograman yang digunakan. Tujuan perawatan ini, mengarah kepada program sistem yang dibuat agar tidak tertinggal oleh perkembangan teknologi.

\section{DAFTAR PUSTAKA}

Amsyah, Zulkifli Drs., MLS., Manajemen Sistem Informasi, Gramedia Pustaka Utama, Jakarta , 2005

Nugroho, Eko, Dr., Ir., M.Si., Sistem Informasi Manajemen : Konsep, Aplikasi, \& Perkembangannya, Andi Yogyakarta, 2008

Oetomo, Budi Sutedjo Dharma, S.Kom., MM., Perencanaan \& Pengembangan System Informasi, Andi Yogyakarta, 2002

Riduwan, Dr., M.B.A., Dasar-dasar Statistika, cetakan ke 8, Alfabeta, Jakarta, 2010

Roy Mubarak, Sistem Cerdas Berbasis Konsep Fuzzy Logic Untuk Evaluasi Kinerja Karyawan, Tekhnologi Informatika, Eresha Jakarta, 2010

Sommerville, Ian, Software Engineering "Rekayasa Perangkat Lunak”, Edisi 6 Jilid 1 dan 2, Erlangga, Jakarta, 2003

Supriyanto, Wahyu, dkk, Teknologi Informasi Perpustakaan "Strategi Perancangan Perpustakaan Digital”, Kanisius, Jakarta, 2008

Wahono, Romi Satrio , Teknologi Informasi untuk Perpustakaan: Perpustakaan Digital dan Sistem Otomasi Perpustakaan, Ilmu Komputer. Com, 2003

Whitten, Jeffrey L., dkk, Metode Desain \& Analisis Sistem, Edisi 6, Andi, Yogyakarta, 2004

Sugiyono, Prof. Dr., Statistika untuk Penelitian, cetakan ke 16, Alfabeta, Jakarta, 2010 